\title{
Pre-service Home Economics Teachers' Attitudes on Selected Aspects of Practical Teaching
}

FranCKa Lovšin KozinA ${ }^{1}$

$\approx$ This paper presents the results of a study conducted among pre-service home economics teachers from the Faculty of Education of the University of Ljubljana with different levels of practical experience in teaching. The pre-service Home Economics teachers in the 3rd year of their studies had just completed their first class of teaching experience in contrast to the pre-service teachers from the 4 th year of their faculty studies, who had conducted more teaching lessons. The results showed that the 4 th-year pre-service teachers had fewer doubts and problems concerning the planning and conducting of a lesson. They also statistically significantly agreed that they are sufficiently prepared to teach than the 3 rd-year pre-service teachers are. The results showed that the majority of the pre-service teachers agreed that the feedback from their colleagues was helpful for their professional development. The results suggest the importance of practical teaching experience in the context of professional development and the intention to continue a career in education. However, the results also revealed some critical points in the teacher's development of competency. The results suggest problems related to the application of theoretical knowledge on the children's development in practice and problems related to classroom management in specific situations.

Keywords: class management, peer learning, pre-service teacher, professional development, teaching experience

1 Faculty of Education, University of Ljubljana, Slovenia; francka.lovsin@pef.uni-lj.si. 


\section{Stališča študentov gospodinjstva o izbranih vidikih poučevanja}

FrancKa LovŠINA Kozina

$\propto$ V članku so predstavljeni izsledki raziskave, izvedene med študenti gospodinjstva Pedagoške fakultete Univerze v Ljubljani, ki so se med seboj razlikovali po obsegu praktičnih izkušenj poučevanja. Študentje tretjega letnika so ravno končali prve nastopne ure, medtem ko so študentje četrtega letnika opravili že več nastopnih ur. Rezultati so pokazali, da so imeli študentje četrtih letnikov manj težav z načrtovanjem in vodenjem učne ure. Statistično značilno so se tudi bolj strinjali, da so dovolj pripravljeni za poučevanje kot študenti tretjega letnika. Rezultati so pokazali še, da se je večina študentov strinjala, da jim je bila povratna informacija njihovih kolegov $\mathrm{v}$ pomoč pri njihovem profesionalnem razvoju. Predstavljeni izsledki kažejo na pomembno vlogo praktične izkušnje poučevanja $\mathrm{v}$ kontekstu profesionalnega razvoja učitelja in namere o nadaljevanju kariere na področju izobraževanja. Rezultati so pokazali tudi nekatere kritične točke v razvoju učiteljevih kompetenc. Nakazujejo se težave, povezane s prenosom teoretičnega poznavanja značilnosti razvojnih stopenj učencev $\mathrm{v}$ prakso in $\mathrm{z}$ vodenjem razreda $\mathrm{v}$ specifičnih situacijah.

Ključne besede: izkušnje poučevanja, profesionalni razvoj, kolegialno učenje, vodenje razreda, študent-učitelj 


\section{Introduction}

One of the global trends in teacher education is a shift to a more practical approach (Moon, 2007). Throughout teaching practice (the systematic guided mentoring process), the mentored student should acquire the teaching knowledge, experience, and skills to become a competent teacher. Labare (2004, p. 45) also asserted the importance of emotions: 'Another characteristic of teaching that makes it difficult is the way it requires teachers to establish and actively manage an emotional relationship with students.' Sutton and Wheatley (2003) noted that several negative emotions in teaching (anger, anxiety, helplessness, stress, etc.) could also appear. Emotions can negatively impact the student's efficacy and self-confidence, but they can also heighten the intrinsic motivation to teach. According to the Self-Determination Theory (Ryan \& Deci, 200o), three fundamental psychological needs (autonomy, competence, and relatedness) should be satisfied in order to foster self-motivation (intrinsic motivation) and well-being (Vansteenkiste \& Ryan, 2013).

Teaching practice provides students an in-depth understanding of themselves, aids in developing skills of planning, leading, evaluating, and assessing their suitability for the teaching profession (Valenčič Zuljan \& Vogrinc, 2012). It is vital that learning through practice often takes place without the student even realising that they are learning (Juriševič, 2007).

Korthagen (2011) developed a so-called 'realistic approach to education', which emphasises concrete, practical problems the teachers experienced in real contexts, and the promotion of systematic reflection, ('gestalt') as the starting point for professional learning, the integration of theory and practice and the integration of several disciplines. Selvi (2010, p. 167) discussed the importance of teachers' competences in the teaching-learning process because: 'Teachers' competencies affect their values, behaviours, communication, aims and practices in school and also they support professional development and curricular studies.' With this in mind, it is fascinating to see how teachers perceive different competences for their teaching success. Malm (2009) studied educators' opinions' on what competences/qualities they considered to be essential to developing teachers from students during their teacher education. The result of this study showed that it was crucial for educators to develop teaching skills, communication skills, leadership qualities, and cognitive capacities (to develop the reflective practitioner). Competences called 'didactic competence' and 'developing children's selfconfidence and personality' were not perceived as being very important.

Fuller (1970 in Akbari, 2007) stated that teachers go through three stages of development. In the first stage, the focus is on themselves; in the second stage, 
the attention is on classroom management and the maintenance of discipline; it is only in the third stage that the teacher has enough confidence in teaching that they can think about improvements in the students' achievement. Therefore, it is imperative to consider how and when to start reflective practice. The development of the capability of professional reflection is crucial. According to Harford and MacRuaire (2008), professional reflection is the essence of a teacher's professional development, because it gives an individual the possibility to change within existing teaching practices (Kemmis \& McTaggart, 1988), and allows teachers to better understand their students' goals and needs (Korthagen \& Kessels, 1999) or, according to Larrivee (2000, p. 293), teaching as a reflective practitioner can help individuals to overcome the possibility of remaining 'trapped in unexamined judgements, interpretations, assumptions, and expectations'. Korthagen and Lagerwerf (1996) stated that the premature introduction of reflective teaching could have inhibitory effects. However, when it is integrated in a proper way, it is a very helpful tool for professional knowledge development of the pre-service teachers. The pre-service-teacher may reflect on feelings for a situation, on teaching strategies, on students' behaviour, and other elements. They can think about what they are doing or 'reflect-in-action' (Schoen, 1983). Education through practical teaching and peer learning is also crucial. Pearson and Stephenson (2005) examined the impact of cooperation between colleagues on reflective thinking. They found that teachers, through conversations with their colleagues, obtain a 'deeper understanding' of their professional development.

In the available literature (OECD, 2005), the problem that many students do not enter the teaching profession is evident. Rots, Aelterman, and Devos (2014) conducted a study in which they tried to identify the predictions of the teacher education graduates' choice of job entry. Their study validated (in addition to initial motivation and labour market factors) the importance of teacher education.

The main goal of teacher education in Slovenia is to provide pre-service teachers with good theoretical knowledge and adequate teacher training through which they can connect theory and practice, develop the necessary teaching skills, routines, and self-confidence. Teaching practice within the subject Didactics of Home Economics in Slovenia occurs in the $3^{\text {rd }}$ year (twoweek duration) and $4^{\text {th }}$ year (two-week duration). The subject Home Economics is taught in the $5^{\text {th }}$ year ( 35 hours/1 hour per week) and in the 6 th year $(52.5$ hours/2 hours per week) in primary school. According to current legislation, this subject can also be taught by a primary school teacher in the 5 th year (frequently realised), but they cannot be mentors to students of the subject. Therefore, problems with the realisation of conducting teaching lessons appear. 
In the ${ }^{3 \text { rd }}$ and $4^{\text {th }}$ years, before pre-service teachers go on their two-week teaching practice, they teach one hour in the presence of a university teacher. Each pre-service teacher must also observe five colleagues teaching. This teaching experience is organised as follows:

- $\quad$ Step 1: university teacher obtains teaching topics from a primary school teacher;

- $\quad$ Step 2: pre-service teachers prepare written material for the lesson, send it via e-mail with possible explanations and questions to the university teacher; the university teacher gives the pre-service teachers feedback and suggestions for improvement;

- $\quad$ Step 3: pre-service teachers carry out a teaching lesson in the presence of the university teacher and five colleagues;

- $\quad$ Step 4: pre-service teachers reflect on their teaching experience and obtain feedback from the university teacher and their colleagues.

The main purpose of the present work was to determine the pre-service teachers' doubts and problems during the preparation stage, their feedback on the realised teaching lesson, their attitudes on their readiness to teach, and also their attitudes towards their colleagues' role in the practical teaching process. This study also aims to examine the adequacy of the existing practical teaching education in the process of the pre-service teachers' development. The difference between the $3^{\text {rd }}$ - and the $4^{\text {th }}$-year pre-service Home Economics teachers was considered. The research questions are as follows:

- Is there a significant difference between the $3^{\text {rd }}$ and the $4^{\text {th }}$-year pre-service Home Economics teachers' sense that they are well prepared to teach?

- Is there a significant difference in the students' sense of their colleagues' role in the practical teaching process between the $3^{\text {rd }}$ and the $4^{\text {th }}$-year pre-service Home Economics teachers?

- Is there a significant difference between the ${ }^{3 \mathrm{rd}}$ - and the $4^{\text {th }}$-year pre-service Home Economics teachers in the case of the students' attitudes towards professional self-development and motivation to a career in the teaching profession?

\section{Method}

This study focused on the pre-service Home Economics teachers at the Faculty of Education of the University of Ljubljana. The research was conducted among all the $3^{\text {rd }}$ - and $4^{\text {th }}$-year pre-service Home Economics teachers $(\mathrm{N}=57)$. 
The pre-service teachers were surveyed at the end of the winter courses (after the obligatory teaching practice in the presence of a university teacher). The sample thus consisted of the pre-service teachers with different levels of practical experience in teaching. Fifty-two questionnaires were returned. The majority of the surveyed pre-service teachers were female (96\%). The surveyed preservice teachers were on average 22.4 years old. The sample included $23(44.2 \%)$ $3^{\text {rd }}$-year pre-service teachers and $29(55.8 \%) 4^{\text {th }}$-year pre-service teachers. The $3^{\text {rd }}$-year pre-service teachers had no teaching experience before observation, which is in contrast to $4^{\text {th }}$-year pre-service teachers, who had, on average, independently conducted 8.59 teaching lessons.

The questionnaire consisted of questions related to (1) the pre-service teachers' opinion on the knowledge of the students' development stages, (2) the doubts and problems faced by the pre-service teachers before and during the performances, (3) the peers' role in the practical teaching learning process, and (4) the pre-service teachers' view on the impact of practical teaching experience on their willingness to become a teacher. The attitudes were measured using the 5-point Likert's scale, where ' 1 ' indicates strong disagreement and ' 5 ' strong agreement. The reliability of the questionnaire was tested. Cronbach Alpha was 0.711 , which indicates that the reliability of the questionnaire is acceptable. The data was statistically processed using the Statistical Package for Social Science (IBM SPSS). Frequency counts were run on all items. For the data analysis, a descriptive analysis was used, and to test the departure from normality the Shapiro-Wilk test was used. The Mann-Whitney U-test was calculated where the significance level of $\mathrm{p}<0.05$ was used (Milenković, 2011).

\section{Results}

For pre-service teachers, it is very important to be familiar with the developmental characteristics of the school children for whom they must prepare lessons. They must prepare appropriate materials, choose the right teaching methods, effectively plan the methodical steps, think about how they will state rules, implement discipline, and how they will make possible modifications to various class conditions, among other factors. The first encounter with 'real' children can be stressful for pre-service teachers. For this reason, it is crucial for them to be able to connect their theoretical knowledge to the psychological/ developmental characteristics of the children with lesson planning (didactical - methodological aspect). 


\section{Pre-service Teachers' Doubts and Problems Before and During Conducting of the Teaching Lesson}

The results (Table 1 ) revealed that the $3^{\text {rd }}$-year pre-service teachers statistically agreed to a greater extent with the statement that they doubted whether primary school children would listen to them $(U=218.50, p=0.02)$. The third year pre-service teachers also statistically more frequently reported problems with the planning of the organisation of lessons than the $4^{\text {th }}$-year pre-service teachers $\operatorname{did}(\mathrm{U}=226.00, \mathrm{p}=0.03)$. Interestingly, the results also showed that the $3^{\text {rd }}$-year pre-service teachers agreed more with the statement that they had a clear idea of the psychological/developmental characteristics of children for which they must prepare lessons than the $4^{\text {th }}$-year pre-service teachers did, but the difference was not statistically significant $(U=280.00, p=0.30)$. It can be assumed that the $4^{\text {th }}$-year pre-service teachers had experience with children, who reacted differently than they had expected, and caused doubt about their theoretical knowledge about children.

As can be seen from Table 1, the pre-service teachers did not report problems with selecting appropriate teaching methods. They had more problems with time management of the planned lesson. The $3^{\text {rd }}$-year pre-service teachers $(M=3.91 ; S D=1.08)$ agreed more that they were afraid they would have time management problems than the $4^{\text {th }}$-year pre-service teachers $(M=3.59$; $\mathrm{SD}=1.25)$. The $3^{\text {rd }}$-year pre-service teachers were more afraid of a conflict situation in which they would not be able to react properly than the $4^{\text {th }}$-year preservice teachers were. However, the $4^{\text {th }}$-year pre-service teachers agreed to a greater extent that they were afraid they would make some professional (content) mistake.

Table 1. Pre-service teachers' view on the preparation stage of teaching practice

\begin{tabular}{|c|c|c|c|c|c|c|}
\hline \multirow{2}{*}{ Statement } & \multicolumn{2}{|c|}{$3^{\text {rd }}$ year } & \multicolumn{2}{|c|}{$4^{\text {th }}$ year } & \multicolumn{2}{|c|}{ Mann-Whitney Test } \\
\hline & M & SD & M & SD & $u$ & $\mathrm{p}$ \\
\hline $\begin{array}{l}\text { Before my lesson, I considered whether } \\
\text { the children would listen to me. }\end{array}$ & 3.70 & 1.14 & 3.07 & 1.10 & 218.50 & 0.02 \\
\hline $\begin{array}{l}\text { In the preparation stage, I had the most } \\
\text { troubles with planning the organisation } \\
\text { of the lesson. }\end{array}$ & 2.83 & 1.26 & 2.14 & 1.12 & 226.00 & 0.03 \\
\hline $\begin{array}{l}\text { I have a clear idea of the psychological/ } \\
\text { developmental characteristics of the } \\
\text { children. }\end{array}$ & 3.35 & 1.19 & 2.97 & 1.29 & 280.00 & 0.30 \\
\hline
\end{tabular}




\begin{tabular}{lccccccc}
\hline \multirow{2}{*}{ Statement } & \multicolumn{3}{c}{$3^{\text {rd }}$ year } & \multicolumn{2}{c}{$\mathbf{4}^{\text {th }}$ year } & \multicolumn{2}{c}{ Mann-Whitney Test } \\
\cline { 2 - 8 } & M & SD & M & SD & U & p \\
\hline $\begin{array}{l}\text { I was afraid that I would have time } \\
\text { management problems. }\end{array}$ & 3.91 & 1.08 & 3.59 & 1.21 & 284.00 & 0.16 \\
\hline $\begin{array}{l}\text { I was afraid that I would make some } \\
\text { professional (content) mistakes. }\end{array}$ & 3.39 & 1.11 & 3.59 & 1.21 & 307.50 & 0.30 \\
\hline $\begin{array}{l}\text { I was afraid of a conflict situation, in } \\
\text { which I would not be able to react } \\
\text { properly. }\end{array}$ & 3.04 & 1.43 & 2.38 & 1.25 & 306.50 & 0.30 \\
\hline
\end{tabular}

Time management, clear instructions, and clear explanations are of great importance for the successful realisation of a teaching lesson. The results (Table 2) showed that the pre-service teachers do not report problems with the clarity of the role statement (time limitations, guidelines) or clarity of statements, but statistically fewer $3^{\text {rd }}$-year pre-service teachers had limited time for a particular activity than the $4^{\text {th }}$-year pre-service teachers did $(U=239.00$; $\mathrm{p}=0.04)$. The $3^{\text {rd }}$-year pre-service teachers also statistically agreed to a greater extent that they had problems with statement articulation $(U=216.50 ; p=0.01)$. Those pre-service teachers who did not have limited time for a certain activity more frequently stated that they had problems with discipline in the classroom.

Table 2. Pre-service teachers' view on problems during teaching lessons

\begin{tabular}{|c|c|c|c|c|c|c|}
\hline \multirow{2}{*}{ Statement } & \multicolumn{2}{|c|}{$3^{\text {rd }}$ year } & \multicolumn{2}{|c|}{$4^{\text {th }}$ year } & \multicolumn{2}{|c|}{ Mann-Whitney Test } \\
\hline & M & SD & M & SD & $U$ & $\mathrm{p}$ \\
\hline $\begin{array}{l}\text { I had problems with the clarity of } \\
\text { guidelines. }\end{array}$ & 2.04 & 1.02 & 1.66 & 0.93 & 254.00 & 0.05 \\
\hline $\begin{array}{l}\text { I did not limit the time needed for a } \\
\text { particular activity. }\end{array}$ & 2.04 & 1.18 & 1.41 & 0.68 & 239.00 & 0.02 \\
\hline I had trouble with statement articulation. & 2.57 & 1.16 & 1.86 & 0.95 & 216.50 & 0.01 \\
\hline
\end{tabular}

The results revealed that the $3^{\text {rd }}$-year pre-service teachers statistically $(\mathrm{U}=158.00, \mathrm{p}=0.00)$ agreed to a greater extent that the most appropriate way of explaining a new lesson was via PowerPoint presentations. It may be assumed that younger pre-service teachers were more occupied with several new aspects of teaching and were more uncertain about the correctness of their behaviour. In the reflection stage (in the presence of the faculty teacher), the students' main argument for using PowerPoint presentations was that they felt 'safer' when they had written some key information. The result also revealed (Table 3) statistically significant differences in the pre-service teachers' need for more didactical-methodological knowledge. The $3^{\text {rd }}$-year pre-service teachers more 
frequently stated that they needed more didactical-methodological knowledge $(\mathrm{U}=185.00, \mathrm{p}=\mathrm{0.00})$ and knowledge on conflict resolution $(\mathrm{U}=245.00, \mathrm{p}=0.03)$.

Table 3. Pre-service teachers' view on what they need to become more successful teachers

\begin{tabular}{lcccccc}
\hline \multirow{2}{*}{ Statement } & \multicolumn{2}{c}{$3^{\text {rd }}$ year } & \multicolumn{2}{c}{$\mathbf{4}^{\text {th }}$ year } & \multicolumn{2}{c}{ Mann-Whitney Test } \\
\cline { 2 - 7 } & M & SD & M & SD & U & P \\
\hline $\begin{array}{l}\text { I want more knowledge about teaching } \\
\text { methods. }\end{array}$ & 4.48 & 0.66 & 3.66 & 1.07 & 185.00 & 0.00 \\
\hline $\begin{array}{l}\text { I want more knowledge about methods } \\
\text { of discipline. }\end{array}$ & 4.39 & 0.65 & 4.03 & 1.05 & 279.50 & 0.24 \\
\hline $\begin{array}{l}\text { I want more knowledge about conflict } \\
\text { resolution. }\end{array}$ & 4.57 & 0.78 & 4.21 & 0.94 & 245.00 & 0.03 \\
\hline
\end{tabular}

The results showed that the $4^{\text {th }}$-year pre-service teachers $(M=4.24$; $\mathrm{SD}=0.63$ ) agreed more that they are sufficiently prepared to teach as opposed to the $3^{\text {rd }}$-year pre-service teachers $(\mathrm{M}=3.17 ; \mathrm{SD}=1.26)$. The difference was also statistically significant $(\mathrm{U}=169.50, \mathrm{p}=0.00)$.

\section{Pre-service Teacher's Attitudes and Perceptions on a Colleague's Role in the Practical Teaching Experience}

Cooperation with colleagues is a key element of the studies as well as later in the teacher's school environment because of the development of reflective practice, which allows for professional and personal growth. The importance of the reflective practice in professional development is described by Akinbode (2013, p. 72) this way: 'My experiences of dialogue through guided reflection within the community of inquiry and of shared reflection on a common event with a colleague have supported my process of transformation.'

Pre-service teachers were asked to provide information related to their perceptions of the role of their colleagues in planning, realising the teaching lesson, and in the closing stage of the teaching experience (evaluation).

The results (Table 4 ) revealed that more $3^{\text {rd }}$-year pre-service teachers talked to their colleagues in the preparation stage about their ideas and about how to realise their teaching lesson than the $4^{\text {th }}$-year pre-service teachers did $(\mathrm{U}=244.00, \mathrm{p}=0.04)$. The $3^{\text {rd }}$-year pre-service teachers further agreed that through the observation lessons of their colleagues, they gained more valuable and useful ideas than the $4^{\text {th }}$-year pre-service teachers did $(U=237.50, p=0.02)$. The $3^{\text {rd }}$-year pre-service teachers also statistically agreed more that after their 
lesson their colleagues reminded them about the errors they did not even realise they had made $(\mathrm{U}=231.00, \mathrm{p}=0.02)$. Both the $3^{\text {rd }}$ - and the $4^{\text {th }}$-year preservice teachers agreed that after the lesson their colleagues gave them some useful feedback. Slightly more $3^{\text {rd }}$-year students agreed with this statement, but the difference was not statistically significant. The $3^{\text {rd }}$-year pre-service teachers also agreed more that the feedback from their colleagues was helpful for their professional development.

Table 4. Pre-service teachers' views on peer learning in practical pedagogical training

\begin{tabular}{|c|c|c|c|c|c|c|}
\hline \multirow{2}{*}{ Statement } & \multicolumn{2}{|c|}{$3^{\text {rd }}$ year } & \multicolumn{2}{|c|}{$4^{\text {th }}$ year } & \multicolumn{2}{|c|}{ Mann-Whitney Test } \\
\hline & $M$ & SD & MD & SD & $U$ & $\mathrm{P}$ \\
\hline $\begin{array}{l}\text { Before my lesson, I talked to my col- } \\
\text { leagues about my ideas on how to } \\
\text { realise my teaching lesson. }\end{array}$ & 3.17 & 1.15 & 2.45 & 1.50 & 244.00 & 0.04 \\
\hline $\begin{array}{l}\text { Through the observation lessons of } \\
\text { my colleagues, I gained valuable ideas, } \\
\text { which I will use in the future. }\end{array}$ & 4.35 & 1.19 & 4.03 & 0.90 & 237.50 & 0.02 \\
\hline $\begin{array}{l}\text { The presence of my colleagues during } \\
\text { my lesson disturbs me. }\end{array}$ & 1.39 & 0.78 & 1.62 & 1.04 & 307.00 & 0.52 \\
\hline $\begin{array}{l}\text { After my lesson, my colleagues re- } \\
\text { minded me about the errors that I did } \\
\text { not even realise I had made. }\end{array}$ & 3.52 & 1.47 & 2.90 & 1.34 & 231.00 & 0.02 \\
\hline $\begin{array}{l}\text { After the lesson, my colleagues gave } \\
\text { me some useful feedback. }\end{array}$ & 3.91 & 1.31 & 3.86 & 1.12 & 309.50 & 0.32 \\
\hline $\begin{array}{l}\text { The feedback from my colleagues was } \\
\text { helpful for my professional develop- } \\
\text { ment. }\end{array}$ & 4.57 & 0.78 & 4.31 & 0.89 & 274.00 & 0.10 \\
\hline
\end{tabular}

\section{Practical Teaching Experience and Motivation for a Career in the Teaching Profession}

Carter, Orr, McGriff, and Thompson (2014, p. 213) state that: 'The classroom management experience plays a vital role in how student or novice teachers view the notion of pursuing a career in education.' In the present research sample, 32 (62.7\%) pre-service teachers agreed that Home Economics was not their first choice for their study. There were also statistically significant differences between the $3^{\text {rd }}$ and $4^{\text {th }}$-year pre-service teachers. More $4^{\text {th }}$-year 
pre-service teachers reported that Home Economics was not their first study choice $(\mathrm{U}=201.00, \mathrm{p}=0.01)$, but when the pre-service teachers were asked if they had thought about another occupation, the difference in answers between the 3 rd and the $4^{\text {th }}$-year pre-service teachers was not statistically significant (Table 5).

Table 5. Pre-service teachers' study choices and motivation for a career in the teaching profession

\begin{tabular}{|c|c|c|c|c|c|c|}
\hline \multirow{2}{*}{ Variable } & \multicolumn{2}{|c|}{$3^{\text {rd }}$ year } & \multicolumn{2}{|c|}{$4^{\text {th }}$ year } & \multicolumn{2}{|c|}{ Mann-Whitney Test } \\
\hline & M & SD & MD & SD & $\mathrm{U}$ & $P$ \\
\hline Home Economics-first study choice & 3.09 & 1.70 & 1.90 & 1.58 & 201.00 & 0.01 \\
\hline $\begin{array}{l}\text { Thinking about choosing another oc- } \\
\text { cupation. }\end{array}$ & 1.83 & 1.11 & 1.69 & 1.13 & 308.50 & 0.67 \\
\hline
\end{tabular}

The results showed that only 7 (13.7\%) pre-service teachers, who stated that the Home Economics programme was not their first study choice, agreed that it was confirmed that they had not chosen the right profession and that they were thinking about other careers through the practical teaching experience. The results also showed that $40(77.0 \%)$ pre-service teachers $\left(17(73.9 \%) 3^{\text {rd }}\right.$-year pre-service teachers and $23(79.3 \%) 4^{\text {th }}$-year pre-service teachers) agreed that they acquired professional self-confidence throughout the practical teaching process. The majority of the pre-service teachers, 30 ( $76.9 \%)$, agreed that they acquired enough professional self-confidence not to think about another occupation through the practical teaching experience. There was no statistically significant difference between the $3^{\text {rd }}$ - and the $4^{\text {th }}$-year pre-service teachers. The results suggest the importance of practical teaching experience in the context of professional self-confidence development and the intention to continue a career in education.

\section{Discussion}

The aim of this research was to determine the possible differences between the $3^{\text {rd }}$ and the $4^{\text {th }}$-year pre-service Home Economics teachers in students preparing and conducting the teaching lesson. The results showed that the preservice teachers with more teaching lessons showed less confidence in knowing the developmental characteristics of the children for whom they must prepare lessons. It can be assumed that they have similar problems as new teachers do, 
who are faced with inconsistencies between their ideals about teaching and their initial teacher experience (Flores, 2006). These findings can also suggest a gap between the pre-service teachers knowing the facts related to the children's personal development, and the student's capability of applying factual knowledge, which also suggests that some improvement in the preparation stage of teaching practice should be made.

The Slovenian researchers Valenčič Zuljan, Zuljan, and Pavlin (2011, p. 493) determine that in the evaluation of learner-centred teaching approaches: 'the practical realisation of one's own lesson and the preparation for a lesson was attributed the highest importance.' The result of the present study showed that the $4^{\text {th }}$-year pre-service teachers, on average, had fewer problems related to planning and realising their teaching lesson. However, the results also showed that, in accordance with Fuller (1970 in Akbari, 2007), the pre-service teachers achieved the second stage of development in which attention is on classroom management and the maintenance of discipline (they wish to have more knowledge on conflict resolution, disciplining, etc.). Practical teaching experience is essential in the development of teaching competences (subject and professional competences), but the pre-service teachers' self-confidence is also a critical dimension: 'Student teachers should feel well-prepared to handle the challenges they will face in the classroom' (Cartre, Orr, McGriff, Thompson \& Willis, 2014, p. 209). The results showed that the $4^{\text {th }}$-year pre-service teachers agreed to a greater extent that they are sufficiently prepared to teach. It can be assumed that practical teaching experience positively impacts the pre-service teachers' perception of the professional preparedness to teach.

Reflection is vital to student's development. One of the six basic principles of the core reflection (which is the basis of a realistic approach to education), exposed the importance of colleagues in reflection; it says that the colleagues' support is more effective than that of the mentors. In this process, the model of collaborative learning can be developed, which can later be applied and used in practice (Korthagen, 2009). The result of the present study highlights the importance of collaborative learning. The results showed that the majority of the pre-service teachers agreed that the feedback from their colleagues was helpful for their professional development and that by observing other students' lessons they get valuable ideas for their teaching. The results also showed that the $4^{\text {th }}$-year pre-service teachers in the preparation stage less frequently talked to their colleagues about their ideas on how to realise their teaching lesson. This can suggest a student-teacher's growing self-confidence and desire to be independent. However, more research should be done to come to a conclusion regarding this. 
For this study, we observed the critical point, which can be problematic in overcoming the gap between theory and practice. The results, as expected, showed the pre-service teachers' progress in communication skills, leadership qualities, didactical-methodical skills, but evidence was found that there were problems with development skills related to class management in specific situations and with skills related to the knowledge and understanding of developmental principles, the differences and the needs of individuals. Nevertheless, the fact is that the number of hours devoted to practical teaching work is quite small. It can be assumed that the extension of time for teaching practice can successfully reduce the problems identified in this study. Some improvements of strategies to prepare the pre-service teachers to show the appropriate reactions in critical class situations should also be considered.

The aim of the present study was also to research what influence the teaching experience has on the pre-service teachers' attitudes towards professional self-development and motivation for a career in the teaching profession. The result showed that in the present research sample, a very high percentage of the pre-service teachers, 32 (62.7\%), agreed that Home Economics was not their first choice for their studies, but only 7 (13.7\%) of them stated that (through the practical teaching experience) it was confirmed that they had not chosen the right profession and that they were thinking about other careers. These results suggest the high motivational value of the teaching practice for entering the teaching profession.

The results also showed that more $4^{\text {th }}$-year students agreed that through the practical teaching process, they acquired professional self-confidence. The results suggested the importance of practical teaching experience in the context of class management and motivation for a career in the teaching profession.

\section{Conclusions}

Practical teaching represents a form of experimental learning in which the pre-service teachers test what they have learned in a real situation. The results of the present study highlight the importance of the practical teaching experience for the professional development of pre-service teachers. The results also revealed some critical points in the pre-service teachers' professional development. There is a need to consider improving some teaching strategies that will help students to manage critical situations (disciplinary problems, conflicts among children or children and teachers, etc.) successfully. The results also showed a gap between the pre-service teachers' factual knowledge of the developmental characteristics of primary school students and the ability 
to apply this knowledge in practical work. For resolving these problems, more study cases and the analyses of video lessons should be prepared. There is also a need to reconsider the concept of practical training in the context of the duration of the teaching practice.

\section{References}

Akbari, R. (2007). Reflections on reflection: A critical appraisal of reflective practices in L2 teacher education. System; An International Journal of Educational Technology and Applied Linguistics, 35(2), 192-207.

Akinbode, A. (2013). Teaching as Lived Experience: The value of exploring the hidden and emotional side of teaching through reflective narratives, Studying Teacher Education: A journal of self-study of teacher education practices, 9(19), 62-73.

Cartre, V., Orr, B., McGriff, M., \& Thompson, C. (2014). Critical Incidents in Classroom Management during Student Teaching Internship and Their Effects on the Teaching Profession: Perceptions of Student Teachers in India and the United States. US-China Education Review, 4(4), 209-228.

Erčulj, J. 2007. Spremljanje in opazovanje pouka [Monitoring and classroom observation]. In M. Brejc, et al. (2007). Ravnatelj kot pedagoški vodja [Headmaster as Pedagogical Leader]. Ljubljana: Šola za ravnatelje.

Flores, M. A. (2006). Being a Novice Teacher in Two Different Settings: Struggles, Continuities, and Discontinuities. Teachers College Record, 108(10), 2012-2052.

Harford, J., \& MacRuaire, G. (2008). Engaging student teachers in meaningful reflective practice. Teaching and Teacher Education, 24(7), 1884-1892.

Juriševič, M. (2007). Praktično pedagoško usposabljanje: vodenje portfolija. Priročnik [Practical Pedagogical Training: Keeping a Portfolio - Hanndbook]. Ljubljana: Faculty of Education, University of Ljubljana.

Kemmis, S., \& McTaggart, R. (1988). The action research planner. Victoria: Deakin University. Korthagen, F. A. J. (2009). Praksa, teorija in osebnost v vseživljenjskem učenju [Praxis, Theory and Personality in Lifelong Learning]. Vzgoja in izobraževanje, 4o(4), 4-14.

Korthagen, F. A. J. (2011). Linking practice and theory: the pedagogy of realistic teacher education. Paper presented at the Annual Meeting of the American Educational Research Association, Seattle. Retrieved 10.10.2014 from http://resources.educ.queensu.ca/ar/aera2001/Korthagen2001.pdf. Korthagen, F. A. J., \& Kessel, J. P. A. M. (1999). Linking theory and practice: Changing the Pedagogy of Education. Educational Researcher, 4(28), 4-17.

Korthagen F.A.J., \& Lagerwerf, B. (1996). Refraiming the relationship between teacher thinking and teacher behaviour: Levels in learning about teaching. Teachers and Teaehing: Theory and Practice 2(2),161-190.

Larrivee, B. (2000). Transforming Teaching Practice: Becoming the critically reflective teacher. 
Reflective Practice: International and Multidisciplinary Perspectives, 1(3), 293-307.

Labaree, D. F. (2004). The trouble with Ed schools. New Haven, CT: Yale University Press.

Malm, B. (2009). Towards a new professionalism: enhancing personal and professional development in teacher education. Journal of Education for Teaching, 35(1), 77-91.

Milenković, Z. M. (2011). Application of Mann-Whitney U test in research of professional training of primary school teachers. Metodicki obzori, 6(1), 73-79.

Moon, B. (2007). Research analysis: Attracting, developing and retaining effective teachers: A global overwiew of current policies and practices. Working Paper of a Research Group on Internatinal Development in Teacher Education. The Open University.

OECD (2005). Teacher Matter: Attracting, Developing and Retaining Effective Teachers. Paris: OECD Publishing.

Pearson, M., \& Stephenson, M. (2005). Developing reflective practice in student teachers: collaboration and critical partnership. Teachers and Teaching: Theory and Practice, 11(1), 95-116. Rots, I., Aelterman, A., \& Devos, G. (2014). Teacher Education graduates' choice (not) to enter the teaching profession: does teacher education matter? European Journal of Teacher Education, $37(3)$, 279-294.

Ryan, R. M., \& Deci, E. L. (2000). Intrinsic and extrinsic motivations: Classic definitions and new directions. Contemporary Educational Psychology, 25(1), 54-67.

Selvi, K. (2010). Teachers' Competencies. International Journal of Philosophy of Culture and Axiology, $7(1), 167-175$.

Schoen, A. D. (1983). The Reflective Practioner. How Professionals Think in Action. USA: Basic Books.

Sutton, R., \& Wheatley, K. (2013). Teachers' emotions and teaching: A review of the literature and directions for future research. Educational Psychology Review. 15(4), 327-358.

Valenčič Zuljan, M., \& Vogrinc, J. (2012). Pedagoška praksa i proces razvijanja kompetencija studenata budućih učitelja razredne nastave Pedagoškog fakulteta Sveučilišta u Ljubljani. [Teaching practice and the process of competence development of future primary school teachers of Faculty of Education in Ljubljana ]. In M. Valenčič Zuljan, J. Vogrinc, G. Gojkov, \& A. Rončević (Eds.), Pedagoška praksa i proces razvijanja kompetencija studenta budućih učitelja u Hrvatskoj, Srbiji i Sloveniji [Teaching practice and the process of competence development of future teachers in Croatia, Serbia and Slovenia] (Biblioteka Istraživačke studije, 47). Vršac: Vaspitačka škola Mihailo Palov.

Valenčič Zuljan, M., Zuljan, D., \& Pavlin, S. (2011). Towards improvements in teachers' professional development through the reflective learning paradigm - the case of Slovenia. Hacettepe Egitim Dergisi, 41(1), 485-495.

Vansteenkiste, M., \& Ryan, R. M. (2013). On psychological growth and vulnerability: Basic psychological need satisfaction and need frustration as a unifying principle. Journal of Psychotherapy Integration, 23(3), 263-280. 


\section{Biographical note}

Francka Lovšina Kozina $(\mathrm{PhD})$ is an Assistant at the Faculty of Education in Ljubljana for the courses Economics of Home Economics, Consumer Education, Basic Textile and Didactic of Home Economics. The main research area is consumer education and financial literacy in primary school, sustainability and pre-service Home economics teachers' praxis. 